\title{
PENDIDIKAN AGAMA KRISTEN UNTUK KELUARGA MENURUT POLA ASUH KELUARGA ISHAK DALAM PERJANJIAN LAMA
}

\author{
Djoys Anneke Rantung \\ Universitas Kristen Indonesia \\ Djoys.anneke@gmail.com
}

\begin{abstract}
Abstrak
Pola asuh dalam keluarga adalah tugas pendidikan agama Kristen yang dilakukan di dalam keluarga sebagai pembentukan karakter dan pertumbuhan iman terutama anakanak. Alkitab memberikan gambaran yang jelas bagaimana pola asuh dari keluargakeluarga baik menurut Alkitab Perjanjian Lama maupun Perjanjian Baru. Kehidupan keluarga Ishak dimulai dari Abraham dan Sarah sebagai orangtua Ishak, kemudian Esau dan Yakub sebagai anak-anak Ishak. Ada pola asuh yang baik dan ada pola asuh yang tidak baik dari keluarga ini. Sesuatu yang baik yang dilakukan akan memberi dampak yang baik bagi pertumbuhan dan perkembangan anak, tetapi sesuatu yang buruk tentu saja sebaliknya dari yang baik. Keluarga berperan penting dalam pembinaan nilai-nilai, memberi dukungan afektif; berupa hubungan kehangatan, saling mengasihi, dan dikasihi, mempedulikan, dan dipedulikan, memberikan motivasi, dan saling menghargai. Penelitian ini dilakukan di Universitas Kristen Indonesia, dengan metode penelitian yang digunakan adalah library research. Untuk menjawab masalah dalam penelitian ini, peneliti meneliti teori-teori yang berkaitan dengan masalah yang diteliti, bersumber dari buku, artikel nasional, dan internasional dalam bentuk prosiding dan jurnal, dokumen, dan sumber lainnya. Temuan penelitian ini adalah bahwa tujuan pola asuh keluarga yang sesuai dengan pendidikan agama Kristen adalah menghasilkan keluarga-keluarga yang berkarakter dengan nilai-nilai kasih dan kepedulian, memiliki motivasi, dan saling menghargai.
\end{abstract}

Kata Kunci: Pendidikan Agama Kristen, Keluarga, Pola Asuh, Keluarga Ishak.

\section{A. Pendahuluan}

Keluarga adalah unit terkecil dari masyarakat yang biasanya terdiri dari ayah, ibu dan anak. ${ }^{1}$ Ada juga keluarga yang terdiri hanya suami dan istri tanpa anak, anak tanpa ayah atau anak tanpa ibu. Dalam keluarga biasanya terjadi sebuah interaksi yang saling bergantung, hingga

\footnotetext{
${ }^{1}$ Keluarga,https://id.Wikipedia.org > wiki > Keluarga, diakses pada tanggal 6 November 2019, pukul 09:25 WIB.
}

terbentuknya suasana kebersamaan. Dalam suasana kebersamaan ini, akan menimbulkan adanya pendidikan dan pengajaran, adanya peran dan tanggung jawab anggota keluarga yang dijalankan sesuai kedudukannya dalam keluarga. Dalam pemahaman yang lebih luas ada istilah keluarga besar yaitu adanya kakek, 
nenek, paman, tante, saudara sepupu, dan lain-lain.

Keluarga yang kuat didasarkan dengan memiliki karakter yang baik. Karakter ini didapatkan dari orangtua yang memberikan teladan yang baik, mengajarkan pendidikan karakter yang baik ke anak, maupun dari anak itu sendiri yang memiliki kemauan untuk mengembangkan karakter yang baik. Orangtua mempunyai mempunyai harapan agar anak-anak mereka tumbuh dan berkembang menjadi anak yang baik, tahu membedakan apa yang baik dan yang tidak baik. Anak tidak mudah terjerumus dalam perbuatan-perbuatan yang dapat merugikan dirinya sendiri maupun merugikan orang lain. ${ }^{2}$

Keluarga adalah sumber stimulasi untuk mempengaruhi perkembangan anak. Peran orangtua dalam menciptakan suasana keluarga mempengaruhi perubahan dan perkembangan anak. Orangtualah yang dapat memastikan pertumbuhan anak, apakah penanganan terhadap anak tersebut bersifat membangun (konstruktif) atau merusak (destruktif). Peran orangtua sebagai pendidik anak sampai dewasa dapat memberi perubahan hidup anak yaitu mental dan perilaku anak yang nantinya akan dibawa ke kehidupan bermasyarakat. Karenanya pembinaan keluarga dilakukan terus menerus sepanjang jalur kehidupan individu dalam keluarga. Jika dari masa kecilnya seorang anak bertumbuh dengan sifat bertanggung jawab, besar kemungkinan ia kelak akan menjadi orang dewasa yang bertanggung jawab. ${ }^{3}$

Menjalankan roda berkeluarga bukanlah semudah membalikkan telapak tangan, sering terjadi kesalahpahaman antara orangtua dan anak atau suami

2 Singgih D.Gunarsa dan Yulia Singgih D. Gunarsa, Psikologi Perkembangan Anak dan Remaja (Jakarta: BPK Gunung Mulia, 1986), 60. dengan istri. Bahkan sampai kepada emosi yang keluar. Perilaku ini umum terjadi di dalam setiap keluarga. Perilaku ini dapat bersifat membangun untuk perbaikan juga dapat berdampak kepada keretakan keluarga. ${ }^{4}$

Keluarga yang matang secara psikologis adalah keluarga yang telah melewati masa-masa sulit sampai terwujud kerukunan dalam keluarga. Ribut sama sekali bukan berarti bahwa pernikahan itu gagal. Ribut itu sendiri bukan tanda buruk. Yang buruk adalah kalau keributan itu dibiarkan berarut-larut, sehingga akibatnya rasa sakit hati dan benci semakin membengkak dan merusak keutuhan rumah tangga. Kerukunan rumah tangga bukan sesuatu yang terjadi dengan sendirinya. Kerukunan harus diusahakan dan ini adalah tanggung jawab bersama anggota keluarga tersebut. ${ }^{5}$

Berdasarkan penjelasan diatas, kita dapat mengetahui tentang keluarga. Keluarga adalah agen utama dalam Pendidikan Agama Kristen untuk memberikan pengajaran kepada anak dari sejak dini. Ada begitu banyak pengajaran dari Alkitab Perjanjian Lama maupun dari Perjanjian Baru, yang dapat kita ambil untuk membangun keluarga yang matang dan takut akan Tuhan. Keluarga para patriarkh (bapa-bapa leluhur) seperti Abraham, Ishak, dan Yakub, memberikan pengaruh besar terhadap hidup segala keturunan dan anggota keluarganya. Kita dapat belajar pola asuh pengajaran dalam kehidupan berkeluarga tokoh Alkitab tersebut untuk dijadikan teladan atau sebuah pembelajaran.

Pendidikan Agama Kristen adalah pendidikan yang berpusat pada Alkitab. Sejarah pendidikan agama Kristen dimulai dari persekutuan Allah dan manusia dalam

\footnotetext{
${ }^{3}$ Andar Ismail, Selamat Ribut Rukun (Jakarta: BPK Gunung Mulia, 2012), 30.

${ }^{4}$ Ibid., 129.

${ }^{5}$ Ibid., 129.
} 
Perjanjian Lama. Bermula saat Tuhan telah memilih dan memanggil Abraham dari jauh untuk melayani kehendak-Nya yang agung guna keselamatan seluruh umat manusia. Bimbingan dan maksud Tuhan itu perlu dijelaskan kepada anak cucunya. Ishak meneruskan ajaran yang penting itu dan kemudian anaknya Yakub pula menanamkan segala perkara ini ke dalam batin anak-anaknya.

Nabi Musa dipilih oleh Tuhan untuk membebaskan umat-Nya dari penindasan. Kita dapat melihat bagaimana peran Allah menuntun mereka selama keluar dari Mesir, perjalanan di Padang Gurun hingga akhirnya sampai di Tanah Perjanjian. Demikianlah kita meninjau masa demi masa, sambil menunjukkan perhatian kita kepada segala aspek pendidikan agama diantara bangsa Israel tatkala sudah mendiami tanah perjanjian itu. Di Israel segala sesuatu harus saling membantu dan bekerja sama untuk mendidik anak-anak dan orang dewasa agar menjadi anggota-anggota persekutuan agama. Seluruh pendidikan itu bersifat agama, dimulai dalam masing-masing rumah tangga, dan diteruskan dalam kebaktian-kebaktian umum dan di dalam pengajaran tentang taurat Tuhan. ${ }^{6}$ Jadi, pendidikan Kristen itu bermula terbentuk dalam kehidupan orang Kristen berdasarkan pendidikan agama Yahudi.

Dalam Perjanjian Baru pendidikan Kristen pertama-tama berpusat pada Tuhan Yesus. Di samping jabatan-Nya sebagai Penebus dan Pembebas, Tuhan Yesus juga menjadi seorang Guru yang Agung. Tuhan Yesus mengajar dimana saja dan kapan pun. Bahkan seluruh kehidupannya merupakan pengajaran sampai saat yang terakhir, karena justru dalam sengsara dan kematian-Nya Ia mengajar kita tentang

${ }^{6}$ I.H.Enklaar dan E.G. Homrighausen, Pendidikan Agama Kristen (Jakarta: BPK Gunung Mulia, 2011), 3-4.

${ }^{7}$ Ibid., 5-8. satu-satunya jalan keselamatan bagi manusia yang berdosa. Kedua, pendidikan Kristen berpusat pada pengajaran Rasul Paulus. Setelah Tuhan Yesus memasuki hidupnya, ia menjadi seorang hamba Tuhan yang terdorong oleh hasrat yang berapi-api untuk memasyhurkan nama Tuhan Yesus. Ini terbukti dengan banyaknya ia mengajar orang Kristen melalui surat-surat yang ia tulis, dan sampai saat ini masih dipakai orang Kristen untuk belajar firman Tuhan. Ketiga, adalah jemaat mula-mula, sejak mulai berdirinya jemaat Kristen ini menjunjung pendidikan agama. Di dalam perkumpulan mereka berdoa, berbicara tentang pengajaran dan perbuatanperbuatan Tuhan Yesus, makan sehidangan dan merayakan Perjamuan Suci. ${ }^{7}$ Pada akhirnya, dari sejarah Perjanjian Lama dan Perjanjian Baru ini menjadikan sejarah lahirnya pendidikan Kristen melalui pengajaran-pengajaran yang diterapkan pada masa itu yang berpangkal pada pengajaran agama Yahudi, dan dijadikan pengajaran pendidikan Kristen sampai saat ini.

Kata Pendidikan berasal dari kata didik yaitu mendidik, mengajar, membimbing atau menuntun bersumber dari bahasa Yunani, Pedagogi yaitu membimbing, menuntun, dan membawa anak kearah yang lebih baik. Alkitab menunjukkan kegiatan pendidikan dalam Perjanjian Lama, seperti: Lamath memukul dengan tongkat, Be'en artinya memahami, Alpah, mengenal dengan dekat, sedangkan dalam Perjanjian Baru terdapat istilah seperti: Didasko, mengajar, Paidemo, membimbing, Katekeo, mengemukakan informasi. ${ }^{8}$ Menurut Kamus Besar Bahasa Indonesia, agama adalah sistem atau prinsip kepercayaan

8 Jhon M. Nainggolan, Guru Agama Kristen Sebagai Panggilan dan Profesi ( Bandung: Bina Media Informasi, 2010), 80. 
kepada Tuhan, atau juga disebut Dewa atau nama lain sesuai ajaran kebaktian dan kewajiban yang berkaitan dengan kepercayaan tersebut. Kata "agama" berasal dari bahasa Sansekerta yang berarti "tradisi", sedangkan kata lain untuk menyatakan konsep ini adalah religi yang berasal dari bahasa Latin "re-ligare" yang berarti "meningkatkan kembali". Maksudnya dengan bereligi, seseorang mengikat dirinya kepada Tuhan. ${ }^{9}$

Agama Kristen di anut oleh persekutuan iman Kristen (orang Kristen). Kristen berasal dari bahasa Yunani Khristos yang diterjemahkan sebagai Mesias (Al Masih), Yang diurapi, abad 1 Masehi, masyarakat yang menyatakan bahwa pengikut Yesus Kristus "seperti Kristus" (Christlike), dan merujuk pada agama Kristen dan pengikutnya, umat Kristen. ${ }^{10}$ Arti yang sedalam-dalamnya dari PAK, bahwa dengan menerima pendidikan itu, semua pelajar muda dan tua, memasuki persekutuan iman yang hidup dengan Tuhan sendiri, dan oleh dalam Dia mereka terhisap pula pada persekutuan jemaat-Nya yang mengaku dan mempermuliakan Nama-Nya di segala waktu dan tempat. 11 Pengertian pendidikan agama Kristen menurut Martin Luther adalah pendidikan yang melibatkan warga jemaat untuk belajar teratur dan tertib agar semakin menyadari dosa mereka serta bersukacita dalam firman Yesus Kristus yang memerdekakan. ${ }^{12}$

Tujuan pendidikan agama Kristen adalah mendewasakan para murid Kristus. "Dan ialah yang memberikan baik rasulrasul maupun nabi-nabi, baik pemberitapemberita Injil maupun gembala-gembala dan pengajar-pengajar, untuk memper-

\footnotetext{
${ }^{9}$ Harianto, G.P., Pendidikan Agama Kristen dalam Alkitab \& Dunia Pendidikan Masa Kini (Yogyakarta: ANDI), 51.

${ }^{10}$ Ibid., 51.

${ }^{11}$ Ibid., I.H. Enklarr, Pendidikan Agama Kristen, 26.
}

lengkapi orang-orang kudus bagi pekerjaan dan pelayanan, bagi pembangunan tubuh Kristus, sampai kita semua telah mencapai kesatuan iman dan pengetahuan yang benar tentang Anak Allah, kedewasaan penuh, dan tingkat pertumbuhan yang sesuai dengan kepenuhan Kristus" (Efesus 4:11-13). Ayat tersebut menunjukkan bahwa tujuan mengajar adalah menjadikan murid dewasa dengan bertumbuh sesuai dengan kepenuhan Kristus. ${ }^{13}$

Pendidikan Agama Kristen untuk Keluarga memberikan banyak pemahaman dengan belajar dari berbagai pengalaman hidup beriman umat Allah dalam Alkitab yang dapat diteruskan oleh keluargakeluarga Kristen sampai masa kini. Keluarga Ishak adalah salah satu model bagaimana keluarga Kristen masa kini dapat meneruskan nilai-nilai kebaikan terutama dalam pola asuh yang baik dalam Pendidikan di keluarga. Keluarga Kristen masa kini dapat belajar bagaimana pola asuh keluarga Ishak untuk meneruskan perintah Allah sebagai dasar kehidupan keluarga.

\section{B. Ishak}

Nenek moyang bangsa Israel adalah Abraham, Ishak, dan Yakub. Abraham dan Sara adalah ayah dan ibu Ishak. Abraham artinya 'Bapa orang beriman'. Ishak adalah anak yang dijanjikan Allah kepada Abraham. Sara melahirkan Ishak pada umur 99 tahun. Dalam bahasa Ibrani Ishak adalah 'yishaq' dan isaak. Kata yishaq berasal dari sahaq yang berarti 'bersuit', 'mengolok-olok', 'menikmati' atau 'mengejek'. Nama Ishak diberikan karena Abraham tertunduk dan

\footnotetext{
12 Paulus Lilik Kristianto, Prinsip \& Praktek Pendidikan Agama Kristen (Yogyakarta: ANDI, 2006), 6.

${ }^{13}$ Kristianto, Op.Cit., 6.
} 
tertawa dalam hatinya sebab ia tidak percaya pada firman Allah bahwa akan diberikan anak ketika ia berumur 100 tahun (Kej. 17:17-19). ${ }^{14}$

Ishak dalam kehidupannya mempunyai latar belakang keluarga ayahnya Abraham yang baik dan buruk. Mengapa dapat dikatakan demikian, karena Abraham mempunyai gundik, yaitu Hagar, yang kemudian melahirkan Ismael, sedangkan yang baik dari latar belakang Ishak, dia adalah anak dari Isteri Abraham yang sah (yang pertama, yaitu Sara), dan sebagai anak yang dijanjikan Allah kepada Abraham. Tentu hal ini juga mempengaruhi pertumbuhan psikologis Ishak.

Ishak tumbuh dalam asah, asih, dan asuh yang baik dari Abraham dan Sara. Hal ini jelas nyata karena Tuhan mau hanya Ishak sang ahli waris tunggal dari apa yang dimiliki Abraham. Sara juga sangat mengasihi Ishak anaknya dan menghendaki Abraham juga melakukan hal yang sama (Kej. 21:10). Ishak mendapatkan kasih sayang yang cukup dari Abraham dan Sara. ${ }^{15}$

Suatu hari, Allah perintahkan Abraham untuk mempersembahkan Ishak sebagai korban bakaran (Kej. 22:1-2). Pada saat Ishak mendaki gunung dengan memikul kayu untuk korban bakaran (Kej. 22:6), Ishak merasakan kejanggalan karena tidak ada hewan untuk korban bakaran, maka ia bertanya kepada ayahnya dimanakah korban bakaran itu, tetapi ayahnya menjawab "Allah yang akan menyediakan anak domba untuk korban bakaran bagi-Nya, anakku" (Kej. 22:8). ${ }^{16}$ Setiba di tempat yang dikatakan Allah, lalu

14 Abraham Park, Pelita Perjanjian Yang Tak Terpadamkan (Jakarta: Grasindo, 2012), 107.

15 Andrew Christian, Keluarga Ishak (12 maret 2009),https://andrewchristian.wordpress.com/2009 /03/12/47/, diakses pada tanggal 02 Mei 2018, pukul 17:00 WIB.

${ }^{16}$ Abraham Park, Op.Cit., 108.
Abraham mengikat Ishak dan membaringkannya di atas kayu api pada mezbah (Kej. 22:9). Ishak yang sudah remaja ini pasti mempunyai kekuatan untuk melawan, tetapi ia taat kepada ayahnya dengan bungkam (Kej. 22:9-10). Ishak memperlihatkan iman yang sempurna dan ketaatan mutlaknya kepada Allah. Allah melihat iman Abraham dan ketaatan Ishak, lalu berfirmanlah Allah "Jangan bunuh anak itu dan jangan kau apa-apakan dia" lalu Allah menyediakan seekor domba jantan yang tanduknya tersangkut pada belukar serta menyuruh Abraham mempersembahkan domba jantan itu sebagai korban persembahan sebagai ganti anaknya (Kej. 22:13-14). Abraham menamai tempat itu "TUHAN menyediakan (YHWH Yireh, Yehowah Yireh) (Kej.22:14). ${ }^{17}$

\section{Riwayat Keluarga Ishak}

Dalam kehidupan Ishak di masa dewasanya, Abraham mencarikan baginya calon isteri yang tepat, yaitu tidak mengambil calon isteri bagi Ishak dari orang kafir melainkan dari sanak saudaranya, yaitu Ribka. ${ }^{18}$ Ishak sangat mencintai Ribka. Ishak berumur 40 tahun ketika Ribka anak Betuel orang Aram dari Padan-Aram, diambilnya menjadi istrinya. ${ }^{19}$ Setelah menikah dengan Ribka, ia harus menunggu lama sekali hingga lahir keturunan yang dijanjikan Allah (Kej. 25:20-21). ${ }^{20}$ Berdoalah Ishak kepada Allah untuk istrinya, sebab istrinya mandul. Lalu Allah mengabulkan doa Ishak, sehingga istrinya mengandung. Tetapi anak-anak dalam rahimnya saling bertolak-tolakan. Sehingga Ribka meminta petunjuk kepada

\footnotetext{
${ }^{17}$ Ibid., 108-109.

${ }^{18}$ Andrew Christian, Op.Cit.

${ }^{19}$ Alkitab dan Kidung Jemaat, (Jakarta: Lembaga Alkitab Indonesia, 2009), 28.

${ }^{20}$ Cristoph Barth dan Marie Claire Barth-Frommel, Teologi Perjanjian Lama 1 (Jakarta: BPK Gunung Mulia, 2012), 69.
} 
Tuhan. Firman Tuhan kepadanya: "Dua bangsa ada dalam kandunganmu, dan dua suku bangsa akan berpencar dari dalam rahimmu; suku bangsa yang satu akan lebih kuat dari yang lain, dan anak yang tua akan menjadi hamba kepada anak yang muda." 21

Ketika Ishak berumur 60 tahun Ribka melahirkan anak kembar laki-laki. Keluarlah yang pertama warnanya merah, seluruh tubuhnya seperti jubah berbulu; sebab itu ia dinamai Esau. Sesudah itu keluarlah adiknya dengan memegang tumit Esau, sehingga diberi nama Yakub (Kej. 25:25-26). Di saat mereka telah besar, Esau menjadi seseorang yang pandai berburu dan suka tinggal di padang. Yakub seorang yang tenang dan suka tinggal di kemah. Ishak sayang kepada Esau, sebab ia suka makan daging buruan, sedangkan Ribka sayang kepada Yakub. ${ }^{22}$

Abraham telah mencapai usia 175 tahun dan telah tinggal di kemah yang sama dengan keluarga Ishak selama 15 tahun (Ibr. 11:9). Yakub yang suka tinggal di kemah (Kej. 25:27) menerima dengan sungguh-sungguh pendidikan iman lewat Abraham, kakeknya, dan Ribka, ibunya sehingga ia mendambakan berkat anak sulung. Hingga pada suatu hari disaat Yakub memasak bubur kacang merah, Esau meminta kacang merah tersebut kepada Yakub karena Esau merasa kelelahan pulang dari padang. ${ }^{23}$ Yakub yang sangat mendambakan hak kesulungan mengambil kesempatan dalam keadaan tersebut. Yakub akan memberikan kacang merah tersebut dengan mengajukan satu syarat, yaitu Esau harus menjual dahulu hak kesulungannya kepada Yakub (Kej. 25:32). ${ }^{24}$ Esau pun bersumpah dan menjual hak kesulungannya kepada Yakub demi sebuah makanan. Dengan demikian,
Esau telah memandang rendah hak kesulungannya (Kej. 25:31, 34). ${ }^{25}$

Ketika Ishak sudah tua dan matanya telah kabur, ia tidak dapat melihat lagi dengan jelas. Maka Ishak pun menyuruh Esau membuat makanan yang ia sukai, agar ia makan dan memberikan berkat anak sulung kepada Esau sebelum ia mati (Kej. 27:4). Ribka mendengar hal tersebut, sehingga di saat Esau berburu, Ribka menyuruh Yakub menyamar menjadi Esau dan memberikan makanan yang telah Ribka masak untuk diberikan kepada Ishak. ${ }^{26}$ Yakub yang telah memperoleh hak kesulungan masuk lebih dahulu ke dalam kemah ayah mereka daripada Esau, kakaknya, dan merampas pula berkat anak sulung (Kej. 5:5). ${ }^{27}$

Ketika Esau mengetahui hal tersebut, ia merasakan kepedihan hati dan menaruh dendam kepada Yakub hingga Esau berencana ingin membunuhnya. Lalu Yakub disuruh ibunya pergi kepada pamannya Laban di Haran untuk melarikan diri dari Esau. Hingga akhirnya Yakub menikah dengan anak pamannya Laban dan mempunyai 12 belas orang anak. Kedua belas anak Yakub inilah menjadi 12 suku bangsa Israel. Begitulah garis besar riwayat singkat kehidupan keluarga Ishak.

2. Masalah-Masalah dalam Keluarga Ishak

Masalah adalah situasi di mana jawaban atau tujuan belum diketahui. Dalam pendidikan karakter seseorang akan dianggap memiliki keterampilan dalam memecahkan masalah apabila ia memiliki 5 kondisi berikut ini, yaitu:

- Memahami dengan jelas kondisi atau situasi yang sedang terjadi.

\footnotetext{
${ }^{25}$ Alkitab dan Kidung Jemaat, Op.Cit., 29.

${ }^{26}$ Ibid., 31.

${ }^{27}$ Abraham Park, Op.Cit., 111.
} 
- Memahami dengan jelas tujuan yang diharapkan.

- Memiliki berbagai tujuan untuk menyelesaikan masalah dan dapat mengarahkan menjadi satu tujuan penyelesaian.

- Memahami sekumpulan sumber daya yang dapat dimanfaatkan untuk mengatasi situasi yang sedang teerjadi sesuai dengan tujuan yang diinginkan.

- Memiliki kemampuan untuk menggunakan berbagai sumber daya untuk mencapai tujuan. ${ }^{28}$

Permasalahan yang terjadi di dalam keluarga Ishak dapat digolongkan ke dalam 4 macam yaitu :

\section{a. Infertil (Kemandulan)}

Hal ini seringkali menjadi pemicu timbulnya masalah dalam keluarga. Ishak menunggu selama 20 tahun untuk mendapatkan anak, tetapi Ishak mampu menghadapinya dengan sabar. Ia berdoa untuk Ribka isterinya, dan doanya didengar oleh Tuhan sehingga Ribka mengandung dan mempunyai anak lakilaki kembar.

\section{b. Ketidaksetiaan}

Ishak mengalami hal yang sama seperti apa yang dialami oleh Abraham bapanya, dia mengalami ketakutan berkenaan halnya dengan Ribka isterinya. Dia berdusta dengan tidak mengakui Ribka sebagai isterinya karena takut dibunuh (Kej. 26:1-8). Kasus yang dialami oleh Ishak ini memang tidak secara serta-merta dialami oleh setiap keluarga di masa sekarang, namun inti dari cerita ini seringkali dilakukan oleh kehidupan keluarga. Baik suami maupun isteri seringkali tidak mau mengakui keberadaan satu sama lain di depan orang banyak,

${ }^{28}$ Imas Kurniasih dan Berlin Sani, Pendidikan Karakter: Internalisasi dan Metode Pembelajaran di Sekolah (Jakarta: Kata Pena, 2017), 120-121. karena adanya ketakutan mendapatkan penghinaan, ejekan ataupun yang lainnya. Kelihatannya hal ini sepele tetapi justru di sinilah awal dari keretakan keluarga. Di mana ada kebohongan, dusta, dan ketidaksetiaan maka dosa perselingkuhan dan perzinahan sudah siap menggerogoti dan mencemari kehidupan kesatuan keluarga. Bukan hanya itu saja di dalam kasus Ishak ini ada suatu egoisme terpendam dalam diri Ishak demi keselamatan dirinya, yaitu agar dia tidak dibunuh oleh orang Filistin. Seharusnya Ishak sebagai kepala keluarga harus memiliki sikap berani dalam membela keluarganya apapun yang nanti akan terjadi, tetapi justru sebaliknya Ishak mencari selamat untuk dirinya sendiri. Namun dalam hal ini Ishak disadarkan oleh Tuhan melalui raja orang Filistin, Abimelekh, supaya Ishak tidak melalukan hal demikian lagi yang dapat menyebabkan orang lain jatuh dalam dosa karena kebohongan yang dilakukan oleh Ishak.

\section{c. Kesenjangan dalam memberi kasih sayang}

Dalam kehidupan keluarga Ishak dan Ribka ada kesenjangan dalam memberikan kasih sayang di dalam keluarga, secara khusus di dalam kehidupan anak-anak mereka, yaitu Esau dan Yakub. Ishak lebih menyayangi Esau, sedangkan Ribka lebih mengasihi Yakub (Kej. 25:28). Dalam keluarga yang harmonis, keadaan seperti ini seharusnya tidak terjadi.

\section{d. Pendidikan dan bimbingan yang kurang dalam keluarga}

Amsal 22:6 menuliskan, "Didiklah orang muda menurut jalan yang patut 
baginya, maka pada masa tuanya pun ia tidak akan menyimpang dari pada jalan itu." Ishak dan Ribka kurang mendidik anak-anaknya dalam pengajaran yang benar. Esau anaknya yang pertama mengambil isteri dari bangsa kafir, dan hal itu menimbulkan kepedihan bagi Ishak dan Ribka, karena mereka tidak suka kepada isteri-isteri dari Esau. ${ }^{29}$ Ishak dan Ribka menyesali keputusan Esau untuk menikah dengan orang kafir.

\section{Pola Asuh Pengajaran Keluarga Ishak}

Ada pola asuh pengajaran yang dapat diketahui dalam keluarga Ishak yaitu adanya pilih kasih antara Ishak dan Ribka kepada anak-anaknya. Ishak sayang kepada Esau karena ia suka makan daging buruan, tetapi Ribka kasih kepada Yakub (Kej. 25:28). Dalam keluarga ini dapat dikatakan, ada anak emas dan anak perak. Kesenjangan kasih sayang dari orangtua terjadi dalam keluarga ini.

Ishak dan Ribka sebagai orangtua tidak memberikan pola pengajaran yang baik kepada anak-anaknya. Mereka tidak mengasihi anak-anaknya dengan sama rata atau seimbang. Sehingga anak-anaknya tidak mendapatkan kasih sayang secara utuh dari kedua orangtuanya. Padahal keluarga adalah agen utama tempat anak untuk mendapatkan perhatian dan kasih sayang dari ayah dan ibu. Akibat dari kesenjangan kasih sayang ini menyebabkan ketidakmerataan kasih dalam keluarga yang berakibat permusuhan di dalam keluarga (Kej. 27:41-42). Hubungan kekeluargaan menjadi rusak dan tidak harmonis. Ini menjadi suatu kegagalan bagi orangtua dalam membina keluarganya.

Kesenjangan kasih sayang yang terjadi di keluarga mengakibatkan orangtua tidak bisa mendidik anaknya secara utuh. Anak tidak dapat mengalami pertumbuhan individu dengan baik. Pertumbuhan individu adalah proses pendewasaan seseorang dalam tahap-tahap perkembangannya secara sosial, kognitif, moral dan iman. Anak yang tidak mendapatkan kasih sayang secara utuh akan mempunyai tahap perkembangan yang kurang atau terlewati.

Keluarga seharusnya berperan penting di dalam pembinaan nilai-nilai, memberi dukungan afektif; berupa hubungan kehangatan, saling mengasihi dan dikasihi, mempedulikan dan dipedulikan, memberikan motivasi, dan saling menghargai. Kemudian adanya pengembangan pribadi yang berupa; kemampuan pola pikir dan emosi, mengenal diri dan orang lain, melaksanakan peran. Keluarga juga berfungsi sebagai penanaman kesadaran atas kewajiban, hak dan tanggung jawab individu terhadap dirinya dan lingkungan. ${ }^{30}$ Sehingga anak dapat memilih jalan yang benar, supaya dikemudian hari tidak akan ada penyesalan di hati orangtua.

\section{Metode Pengajaran Keluarga Ishak}

Di dalam Alkitab tidak ditulis secara langsung bagaimana metode pengajaran yang dilakukan dalam keluarga Ishak. Akan tetapi kita dapat menyimpulkan metode pengajaran yang diberikan itu secara berulang-ulang dan turun temurun. Isi pengajarannya berkaitan dengan nilai-nilai hidup yang sesuai dengan kehendak Tuhan. Hal ini dapat kita lihat dari kehidupan Yakub misalnya, biarpun ia lari meninggalkan rumah ayahnya, Ishak, justru dalam persaingannya itu ia senantiasa mengingat keluarganya dan masih tetap mengatur tingkah-lakunya menurut adat dan asasasas rumah tangga yang telah diajarkan

\footnotetext{
${ }^{30}$ Gunarsa, Op.Cit., 60.
} 
kepadanya. ${ }^{31}$ Yakub mendapatkan ajaran tersebut karena ia suka tinggal di kemah (Kej. 25:27) sehingga ia menerima dengan sungguh-sungguh pendidikan iman lewat Abraham, kakeknya, dan Ribka, ibunya.

Besar kemungkinan Yakub menerima pengajaran dari kakeknya secara langsung dan secara berulang-ulang karena mereka tinggal di dalam kemah yang sama (Ibr. 11:9). Yakub menjadikan kakeknya sebagai teladan dalam kehidupannya beriman kepada Tuhan. Sehingga pengajaran itu melekat di dalam diri Yakub kemana pun ia pergi. Sedangkan Esau karena ia suka berburu dan tinggal di padang sehingga ia tidak menerima pengajaran dengan baik melalui Abraham dan kedua orangtuanya. Hal ini dapat kita lihat dari bagaimana Esau menganggap ringan hak kesulungannya (Kej. 25:31, 34). Ini mengambarkan kurangnya Esau mendapatkan sebuah pengajaran atau pendidikan iman dari keluarganya.

Berdasarkan metode pengajaran yang ada dalam keluarga Ishak dapat disimpulkan bahwa metode pengajaran itu harus dilakukan sejak dini, turun-temurun dan berulang-ulang. Anak-anak harus lebih banyak menghabiskan waktu dengan keluarganya di rumah, agar anak mendapatkan pendidikan yang maksimal. Jadi orangtua harus menciptakan keadaan dan suasana yang senyaman mungkin bagi anak, sehingga anak betah dan senang berada di rumah.

5. Tahap-tahap Perkembangan dalam Keluarga Ishak

Ada 4 teori tahap-tahap perkembangan yang terjadi dalam kehidupan manusia yaitu psikososial, kognitif, moral, dan iman. Berdasarkan teori tersebut maka tahap perkembangan dalam keluarga Ishak, yaitu:

\footnotetext{
${ }^{31}$ I.H.Enklaar dan E.G. Homrighausen, Op.Cit., 129.
}

\section{a. Tahap Perkembangan Psikososial}

Dalam tahap perkembangan psikososial dari segi teori Erickson kepercayaan versus tidak percaya sepertinya Esau menjadi anak yang tidak mudah percaya kepada orang lain. Hal ini disebabkan karena ia kurang mendapatkan kasih sayang dan perhatian dari ibunya waktu kecil. Sedangkan Yakub menjadi anak yang mudah ragu-ragu dan malumalu karena ia kurang mendapatkan kasih sayang dan perhatian dari ayahnya. Sehingga anak-anak Ishak menurut teori ini tidak mempunyai perkembangan psikososial yang matang, karena tidak mendapatkan kasih sayang yang utuh dari kedua orangtua.

\section{b. Tahap Perkembangan Kognitif}

Dalam keluarga Ishak sepertinya mereka belum menyelesaikan tahap perkembangan ini dengan baik. Sebab di dalam keluarganya mereka seperti kurang berinteraksi satu dengan yang lainnya untuk bertukar ide. Ishak dan Ribka jarang berdiskusi dalam mengambil keputusan, tidak berdasarkan keputusan bersama. Hal ini disebabkan karena kesenjangan kasih sayang sehingga orangtua hanya cenderung sering berinteraksi dengan anak yang ia sayang. Esau dan Yakub pun jarang berinteraksi sebagai saudara. Ini dapat dilihat dari hobi mereka yang berbeda, Esau suka di ladang dan Yakub yang suka di kemah. Akhirnya, hal ini mengakibatkan anak-anak tidak mempunyai secara utuh aspek-aspek perkembangan kognitif di dalam dirinya.

\section{c. Tahap Perkembangan Moral}

Pada tahap perkembangan moral, sepertinya Yakub dan Esau masih belum mencapai tingkat pascakonvesional dalam 
perkembangan moral. Ini dapat dilihat dari bagaimana cara Yakub untuk mendapatkan berkat anak sulung dari ayahnya, ia melakukan tipu daya terhadap ayahnya. Ketika Esau mendengar berkat anak sulungnya telah diambil Yakub, ia menjadi dendam kepada Yakub dan mengambil keputusan untuk membunuh Yakub. Dapat simpulkan dari kedua hal ini bahwa Esau dan Yakub masih belum mendapatkan pengajaran tentang moral yang baik dari kedua orangtuanya. Ini terbukti dengan Ishak dan Ribka tidak bisa menjadi teladan yang baik bagi anaknya. Ribka sebagai seorang ibu mengajarkan anaknya Yakub untuk menipu ayahnya dengan menyamar menjadi Esau. Ishak yang meminta makanan kepada Esau sebelum memberkatinya. Ini menunjukkan Ishak menganggap berkat istimewa itu setara dengan makanannya. Tidak heran jika Esau menganggap ringan akan hak kesulungannya dan menukarkannya dengan makanan, karena meniru dari ayahnya. ${ }^{32}$

\section{d. Tahap Perkembangan Iman}

Pada segi tahap perkembangan iman di keluarga Ishak kita dapat menyimpulkan bahwa Ishak dan Ribka sudah berada dalam iman conjunctive yaitu tahap iman yang dewasa. Esau dan Yakub pada saat itu tahap imannya berada pada iman individual-reflektif yaitu tahap iman pada masa akhir remaja dan awal dewasa. Mereka mulai mencari-cari jati diri iman mereka dengan permasalahan yang terjadi dalam keluarga mereka. Dalam tahap iman ini, fokus seseorang biasanya pada tanggung jawabnya sebagai seorang dewasa terhadap komitmen dan kepercayaannya sendiri meragukan, mempertanyakan, dan menolak asumsi- asumsi tradisional. Ini adalah periode dimana nilai-nilai individu akan berkembang. ${ }^{33}$

Berdasarkan tahap-tahap perkembangan tersebut, disimpulkan bahwa orangtua memegang kendali penuh agar anaknya mengalami pertumbuhan individu secara menyeluruh dari aspek psikososial, kognitif, moral, dan iman. Orangtua adalah pemberi kasih sayang yang mendasar. Orangtua berpengaruh kuat terhadap perkembangan psikologi anaknya dari sejak kecil. Orangtua yang mengabaikan anaknya akan menghalangi perkembangan psikologi yang sehat. Hal yang mendukung perkembangan psikologi anak yang perlu diketahui dan disikapi oleh orangtua maupun yang akan menjadi orangtua yaitu menerima anak tanpa syarat dan memberikan stimulasi. ${ }^{34}$ Jika orangtua tidak melakukan hal ini dan tidak belajar dari kehidupan keluarga Ishak, maka akan berdampak buruk bagi anak dan keluarga.

\section{Relevansi bagi PAK Keluarga}

Relevansinya bagi PAK keluarga adalah kita dapat belajar dari kehidupan keluarga Ishak bagaimana cara untuk membentuk keluarga yang harmonis dan takut akan Tuhan. Keluarga adalah tempat pertama pembentukan kepribadian. Keluarga Kristen adalah pemberian Tuhan yang tak ternilai harganya. Keluarga memegang peranan penting dalam pengajaran agama Kristen. Keluarga mempunyai tempat yang mutlak dalam sejarah suci. Di dalam Alkitab kita menyaksikan pentingnya keluarga yang dipakai oleh Tuhan sebagai saluran dan jalan keselamatan yang dirancangkan Tuhan bagi umat manusia. Pendidikan dalam keluarga merupakan dasar bagi seluruh pendidikan lainnya dalam

\footnotetext{
34 Junihot Simanjuntak, Psikologi Pendidikan
} Agama Kristen (Yogyakarta: ANDI, 2016), 98-99.

\footnotetext{
32 Jarot Wijanarko, Intim - Orangtua - Anak Keluarga Indonesia Bahagia, 80-81.

${ }^{33}$ Pazmino, Op.Cit., 298.
} 
masyarakat umat Tuhan pada Perjanjian Lama. ${ }^{35}$

"Apa yang kuperintahkan kepadamu pada hari ini haruslah engkau perhatikan haruslah engkau mengajarkannya berulang-ulang kepada anak-anakmu dan membicarakannya apabila engkau duduk di rumahmu, apabila engkau sedang dalam perjalanan, apabila engkau berbaring dan apabila engkau bangun. Haruslah juga engkau mengikatkannya sebagai tanda pada tanganmu dan haruslah itu menjadi lambang di dahimu, dan haruslah engkau menuliskannya pada tiang pintu rumahmu dan pada pintu gerbangmu" (U1. 6:6-9). "Didiklah anakmu, maka ia akan memberikan ketentraman kepadamu, dan mendatangkan sukacita kepadamu" (Ams. 29:17). Dari penulisan ayat ini, peranan orangtua dalam keluarga tampak jelas dalam tanggung jawabnya untuk mengajarkan perintah Allah kepada mereka. ${ }^{36}$ Inilah yang menjadi dasar atau cikal bakal bagi orangtua dalam mengajarkan PAK di dalam keluarga.

Orangtua Kristen harus menerapkan tiga aspek mendidik anak dalam keluarga yang sesuai pandangan Alkitab yakni:

1. Aspek mengasuh, contohnya Abraham dalam mengasuh/merawat Ishak.

2. Aspek mendidik/mengajar, contohnya imam Eli yang salah dalam mendidik anak-anaknya. Contoh ini memang salah, tetapi bisa dijadikan contoh bagaimana orangtua memang punya kewajiban untuk mendidik anaknya, namun tidak boleh salah mendidik. Orangtua harus mendidik anakanaknya sesuai dengan kehendak Tuhan (1 Sam. 2: 22-25, 29).

3. Aspek memperlengkapi (Ef. 4:12). ${ }^{37}$

\footnotetext{
${ }^{35}$ I.H. Enklaar, Op.Cit., 129-130.

${ }^{36}$ Harianto GP, Pendidikan Agama Kristen dalam Alkitab \& Dunia Pendidikan Masa Kini, (Yogyakarta: ANDI, 2012), 73.
}

Selain dari ketiga aspek tersebut, ada berbagai metode penyampaian pendidikan agama Kristen dalam Perjanjian Baru yang dapat digunakan dalam PAK keluarga. Metode-metode tersebut yaitu memenangkan perhatian, menggunakan pertanyaan, menggunakan ilustrasi menggunakan ceramah dan menggunakan model. Metode tersebut dapat dilihat dari Yesus Sang Guru Agung dalam pengajaran serta pelayanan-Nya, dan masih banyak lagi metode masa kini yang dapat dipakai dalam pengajaran. ${ }^{38}$

\section{Refleksi Kritis}

Keluarga Ishak telah menjadi sebuah pembelajaran bagi keluarga Kristen untuk membentuk keluarga yang utuh dan takut akan Tuhan. Berdasarkan cerita kehidupan keluarga Ishak banyak hal yang dapat dijadikan pembelajaran bagi keluarga Kristen saat ini. Kegagalan Ishak dan Ribka dalam memberikan pendidikan dan pembinaan bagi anaknya menjadi bahan pertimbangan dalam keluarga kita. Apakah kita juga menerapkan pola pengajaran seperti itu atau tidak ? Jika iya, alangkah baiknya kita mengubah pola pengajaran tersebut, dan jika tidak kita harus bersyukur karena telah memberikan pola pengajaran yang tepat, tetapi kita juga harus mengambil hal-hal positif dari keluarga Ishak apa yang dapat diterapkan dalam keluarga kita.

Persoalan ini bukan hanya menjadi persoalan keluarga saja, tetapi ini juga menjadi persoalan bagi gereja. Oleh sebab itu, maka sangat dibutuhkan pembinaan bagi keluarga Kristen. Kontribusi pertama yang dapat diberikan gereja kepada pembinaan keluarga Kristen yaitu penerangan dan bantuan rohani kepada

\footnotetext{
37 John Virgil Milla, Peranan Keluarga Dalam Pengajaran PAK Terhadap Pertumbuhan Rohani, (Jakarta: YAKI, 2012), 31.

${ }^{38}$ Ibid.,32.
} 
orang muda yang menyiapkan diri bagi pernikahan kudus. ${ }^{39}$

Kaum muda ini biasanya menaruh minat yang besar dalam persoalan pernikahan dan keluarga. Hendaknya pendeta-pendeta memakai kesempatan yang baik ini untuk memberikan penerangan yang tegas tentang wujud dan fungsi pernikahan Kristen. Dalam hal ini, pendeta juga harus menguraikan masalahmasalah yang dapat terjadi dalam pernikahan, bahaya-bahaya dan kemungkinan-kemungkinan hidup dalam berkeluarga. Gereja juga harus berusaha membantu dan memimpin keluarga itu terus menerus, supaya keluarga muda itu senang di dalam persekutuan jemaat yang luas. $^{40}$

Gereja dapat membentuk komunitas bagi keluarga-keluarga muda. Dengan begitu keluarga dari sejak pernikahannya mendapatkan petunjuk dan pertolongan dalam mengatur rumah tangganya, supaya suasana Kristen dalam rumahnya terasa setiap hari, karena mereka menimba kekuatan dan kesegarannya dari Firman Tuhan dan dari doa dan nyanyian mereka bersama. ${ }^{41}$ Gereja juga harus bertanggung jawab terhadap pemimpin keluarga Kristen dalam baptisan kudus terhadap anak. Suami-istri tersebut harus menerima pengajaran tentang baptisan kudus anak. Ini menjadi kesempatan yang baik bagi gereja untuk membicarakan dengan kedua orangtua tentang tugas dan tanggung jawab mereka dalam pendidikan rohani anak-anaknya. Sebab itu sudah seharusnyalah pendeta menjadi sahabat karib bagi segala keluarga dalam jemaatnya. ${ }^{42}$

Gereja perlu menawarkan bantuannya kepada keluarga Kristen dalam

\footnotetext{
${ }^{39}$ I.H. Enklaar, Op.Cit., 133.

${ }^{40}$ Ibid., 134.

${ }^{41}$ Ibid., 135.

${ }^{42}$ Ibid., 135.

${ }^{43}$ Ibid., 136.
}

suka dan duka. Gereja juga harus memberikan perhatian kepada semua anak keluarga jemaat agar rajin mengikuti kegiatan Sekolah Minggu dan pengajaran Pendidikan Agama Kristen lainnya seperti katekisasi. Tetapi yang lebih penting dari semua ini adalah orangtua harus ditolong agar dapat membina rumah tangganya sehingga kasih Kristus memerintah di dalam keluarganya. ${ }^{43}$

Orangtua harus menyadari bahwa pengajaran Pendidikan Agama Kristen dalam keluarga bukan hanya melalui sebuah perkataan saja. Pengajaran itu harus disertai dengan sebuah tindakan, karena "iman tanpa perbuatan pada hakekatnya adalah mati” (Yak. 2:14-26). Pengajaran kepada anak menuntut keteladanan dari orangtua. Suasana rumah dalam keluarga yang rukun juga mempengaruhi sebuah pengajaran kepada anak-anak.

Anak-anak yang di asuh dengan pendekatan pola asuh positif akan berkembang dengan baik, memiliki kemampuan baik, dan selalu merasa nyaman akan dirinya sendiri atas segala hasil yang telah dicapainya. Pendekatan pola asuh positif akan mengembangkan kebiasaan baik yang merupakan landasan positif dalam mengembangkan karakter positif anak. ${ }^{44}$ Berbahagialah gereja jika mempunyai banyak keluarga Kristen yang sejati. Apa yang dipelajari anak dalam keluarganya sejak kecil tidak akan hilang begitu saja kemana pun ia pergi, sama halnya seperti Yakub yang tetap memegang pengajaran yang ada dalam keluarganya dimanapun ia berada. Jadi dasar-dasar hidup rohani manusia diletakkan pada masa mudanya, yakni di dalam keluarganya sendiri. ${ }^{45}$

\footnotetext{
${ }^{44}$ Hanny Muchtar Darta, Positive Characters With Positive Parenting (Jakarta: Kompas Gramedia, 2014), 14.

${ }^{45}$ I.H. Enklaar, Op.Cit., 137.
} 


\section{E. Kesimpulan}

Anak adalah anugerah Tuhan yang harus dibina dan diberikan pengajaran dengan baik. Lingkungan keluarga menjadi tempat pertama dalam pembentukan karakter yang baik kepada anak. Pola pengajaran yang diberikan kepada anak menentukan keberhasilan seorang anak dari aspek sosial, kognitif, moral, dan iman.

Keluarga Ishak menjadi sebuah contoh bagi keluarga Kristen saat ini untuk dapat membina keluarganya dengan baik. Keluarga Kristen dapat menilai pola pengajaran seperti apa yang ia harus terapkan dalam rumah tangganya. Pola pengajaran yang positif dalam keluarga Ishak dapat ia ambil, sedangkan pola pengajaran yang negatif janganlah diambil. Jadi, hendaklah sebagai orangtua memberikan pola asuh yang tepat kepada anak-anak dari sejak dini agar dapat mengalami pertumbuhan individu dengan baik dari aspek sosial, kognitif, moral, dan iman.

Keluarga itu diibaratkan sebagai kapal yang berlayar dalam sebuah lautan. Banyak gelombang dan angin ribut yang akan menerjang kapal tersebut hingga dapat tenggelam ataupun karam. Seperti itulah sebuah keluarga banyak persoalan yang akan datang silih berganti. Tetapi jika keluarga itu mempunyai Yesus sebagai nahkoda kapalnya maka Ia akan menyertai keluarga itu dalam menghadapi pergumulan dan akan memberikan jalan keluar (1 Kor. 10:13).

Berdasarkan hal ini dapat disimpulkan, bahwa tidak selamanya kehidupan berkeluarga akan berjalan dengan baik. Ada saatnya masalahmasalah akan datang silih berganti. Semuanya tergantung di dalam diri kita apakah akan berjuang sampai akhir atau melarikan diri. Akan tetapi alangkah baiknya masalah yang terjadi itu harus dihadapi, bukan dihindari. Kita sebagai orang percaya harus memohon tuntunan Tuhan agar kita sekeluarga selalu dimampukan melewati setiap pergumulan yang ada agar kita menjadi keluarga yang berfondasi kuat di dalam Yesus Kristus.

\section{F. Saran}

Saran yang dapat saya berikan kepada keluarga masa kini berdasarkan pembahasan tentang Keluarga Ishak ialah: Jika anak dibesarkan dengan celaan, ia belajar memaki. Jika anak dibesarkan dengan permusuhan, ia belajar berkelahi. Jika anak dibesarkan dengan cemoohan, ia belajar rendah diri. Jika anak dibesarkan dengan penghinaan, ia belajar menyesali diri. Jika anak dibesarkan dengan toleransi, ia belajar menahan diri. Jika anak dibesarkan dengan pujian, ia belajar menghargai. Jika anak dibesarkan dengan sebaik-baik perlakuan, ia belajar keadilan. Jika anak dibesarkan dengan rasa aman, ia belajar menaruh kepercayaan. Jika anak dibesarkan dengan dukungan, ia belajar menyenangi diri. Jika anak dibesarkan dengan kasih sayang dan persahabatan, ia belajar menemukan cinta dalam persahabatan (Dorothy Law Nolte). ${ }^{46}$

Jadi, bagaimanapun kondisinya adalah tugas orangtua untuk membangun kedekatan dengan anaknya. Kedekatan antara orangtua dan anak akan menjadi fondasi penting bagi tumbuh kembang anak, pembentukan karakter anak dan akan mempengaruhi kecerdasan si anak. Semoga pembahasan tentang "PAK dalam Keluarga Ishak" dapat menjadi sebuah pembelajaran yang berharga bagi keluarga Kristen pada masa kini.

\section{G. Referensi}

Azmino, R.W. Fondasi Pendidikan Kristen. Jakarta: BPK Gunung

${ }^{46}$ Junihot Simanjuntak, Op.Cit., 97. 
Volume 3 Nomor 2 Tahun 2019 hal. 63-76

Mulia, 2016.

Barth, Cristoph dan Marie Claire BarthFrommel. Teologi Perjanjian Lama 1. Jakarta: Gunung Mulia, 2012.

Darta, H.M. Positive Characters With Positive Parenting. Jakarta: Kompas Gramedia, 2014.

Enklaar I.H. dan E.G. Homrighausen, Pendidikan Agama Kristen. Jakarta: BPK Gunung Mulia, 2011.

GP, Harianto. Pendidikan Agama Kristen dalam Alkitab \& Dunia Pendidikan Masa Kini. Yogyakarta: ANDI, 2012.

Gunarsa, S.D dan Yulia Singgih D. Gunarsa. Psikologi Perkembangan Anak dan Remaja. Jakarta: BPK Gunung Mulia, 1986.

Ismail, Andar. Selamat Ribut Rukun. Jakarta: BPK Gunung Mulia, 2012.

Kristianto, P.L. Prinsip \& Praktek Pendidikan Agama Kristen. Yogyakarta: ANDI, 2006.

Kurniasih, Imas dan Berlin Sani. Pendidikan Karakter: Internalisasi dan Metode Pembelajaran di Sekolah. Jakarta: Kata Pena, 2017.

Milla, J.V. Peranan Keluarga Dalam Pengajaran PAK Terhadap Pertumbuhan Rohani. Jakarta: YAKI, 2012.

Nainggolan, J.M. Guru Agama Kristen Sebagai Panggilan dan Profesi. Bandung: Bina Media Informasi, 2010.

Park. Abraham, Pelita Perjanjian Yang Tak Terpadamkan. Jakarta: Grasindo, 2012. 
